\title{
JAKIEJ KULTURY \\ POLACY POTRZEBUJĄ? ANTYIRRACJONALIZM WOBEC DYLEMATÓW CYWILIZACYJNYCH
}

\section{Uwagi wstępne}

Ponad dwieście lat temu na publicznym posiedzeniu Akademii Krakowskiej ks. prof. Feliks Jaroński, „nauczyciel filozofii” (jak sam o sobie mówił), wygłosił odczyt pod znamiennym tytułem: Jakiej filozofii Polacy potrzebują? (Jaroński [1810] 1970) ${ }^{1}$. Do tego właśnie tytułu, wykorzystanego zresztą w antologii wydanej przez Władysława Tatarkiewicza, gdzie znalazł się także ów odczyt Jarońskiego, nawiązuje tytuł mojego tekstu.

W rozdziale nawiązywać będę jednak nie do Jarońskiego, lecz do działającego sto lat później Kazimierza Twardowskiego, twórcy Szkoły Lwowsko-Warszawskiej, której program filozoficzny streszcza się w haśle antyirracjonalizmu wymyślonym przez Kazimierza Ajdukiewicza, ucznia i zięcia Twardowskiego. Postawa antyirracjonalna, przeciwstawiająca się wszelkiej spekulacji myślowej i wszelkiej mętności językowej, stała się czymś charakterystycznym dla uczniów Twardowskiego, uczniów jego uczniów i kolejnych pokoleń filozofów przyznających się do lwowsko-warszawskiej tradycji. Tradycja ta rozwijana jest także w ośrodku łódzkim, a w nim jedną z centralnych postaci jest prof. Ryszard Kleszcz, który zresztą problematyce antyirracjonalizmu poświęcił w swoim dorobku wiele uwagi.

Tytułową kulturę rozumiem szeroko: jako ogół artefaktów i aktów, które te artefakty powołują do istnienia. Z dylematami, o których mówię poniżej, zmierzyć się muszą wszyscy poważni twórcy kultury. Może więc będzie dla nich pomocą zapoznanie się z tymi rozwiązaniami owych dylematów, które proponowali Twardowski i - szerzej-członkowie jego Szkoły.

${ }^{1}$ Warto jednak wspomnieć, że ks. Jaroński prezentował wizję filozofii polegającą na „krytycznym roztrząsaniu” zagadnień. Uważał, iż zadaniem filozofii jest odpowiedzieć na pytania, takie jak: czym jestem?, co mogę wiedzieć?, czego się mam spodziewać?, co mi czynić wypada? - ale przy użyciu „samego rozumu”, a nie - kościelnych autorytetów. W tym zakresie wolno myśl Jarońskiego uznać za antycypację antyirracjonalizmu Szkoły Lwowsko-Warszawskiej. 
Dlaczego tłem moich uwag są Twardowski i Szkoła Lwowsko-Warszawska? Jednym z powodów jest, rzecz jasna, to, że - jak już wspomniałam - do tradycji Szkoły nawiązuje i tradycję tę bada prof. Kleszcz, któremu tekst ten jest dedykowany. Do tego dochodzi też to, że i moje zainteresowania naukowe dotyczą w dużym stopniu szkoły Twardowskiego. Nie są to jednak powody ani jedyne, ani nawet główne. Główny powód jest taki, że Szkoła Twardowskiego była jedynym w dwudziestowiecznej kulturze polskiej wielkim przedsięwzięciem zbiorowym, które - twierdzę - pod względem zasięgu i wpływu nie ma sobie równych w dziejach Polski, a niewiele ma równych w świecie. Warto uwzględnić opinie tych, którym się udało coś takiego zrobić.

W poniższych uwagach wykorzystuję uwagi Twardowskiego zarówno o sprawach ogólnokulturowych, jak też o samej dziedzinie jego badań: filozofii. Ekstrapolując uwagi Twardowskiego na temat filozofii na problematykę kultury in toto, dokonuję wielkiego uogólnienia, którego koniecznym kosztem jest niejedno uproszczenie. Powołuję się przy tym przede wszystkim na teksty Twardowskiego będące jego pracami nie ściśle teoretycznymi, lecz programowymi. Są to głównie przemówienia, teksty okolicznościowe i wspomnieniowe. Problematyki, którą tu poruszam, Twardowski w swojej działalności stricte naukowej nie podejmował, uważając, że narzędzia filozoficzne są nie dość dojrzałe do tego, aby poglądy w tych sprawach należycie na gruncie filozofii wyrazić i uzasadnić. Nie znaczy to jednak, że poglądów tych nie można poddawać analizie, a w tym badać, czy wynikają z nich jakieś wskazówki co do postawy, jaką można przyjąć wobec aktualnych dylematów cywilizacyjnych.

Dylematów, przed którymi stoi kultura, w szczególności kultura polska, jest wiele. Niektóre z nich są stare; niektóre pojawiły się stosunkowo niedawno.

Pierwszy i podstawowy dylemat, przed którym stoją dziś twórcy kultury, wyraża się następująco: wierność „uporządkowanej” cywilizacji grecko-łacińskiej czy jej porzucenie na rzecz propagowanego od pewnego czasu w świecie zachodnim postmodernistycznego chaosu?

Cywilizacja grecko-łacińska opiera się na prymacie trzech wartości: prawdy, dobra i piękna, do których dodać jestem skłonna - co nie powinno dziwić kogoś, komu leży na sercu polska wersja tej cywilizacji - wartość czwartą: wolność. Czterem tym wartościom odpowiadają cztery sfery kultury: wolności - kultura polityczna, prawdzie - kultura logiczna, dobru - kultura etyczna, pięknu - kultura artystyczna. W rozdziałach 3-5 przyjrzę się bliżej kolejno tym sferom kultury i ich dylematom. Wcześniej jednak, w rozdziale 2, omówię krótko podstawę sukcesu Szkoły Lwowsko-Warszawskiej. 


\section{2. Źródła sukcesu Szkoły Lwowsko-Warszawskiej}

Za początek Szkoły przyjmuje się rok 1895, kiedy Twardowski przybył do Lwowa i zaczął uczyć filozofii w miejscowym uniwersytecie. Co ważniejsze - stał się promotorem własnych doktorów. Pierwszymi byli nie byle kto: Jan Łukasiewicz, twórca Polskiej Szkoły Logicznej, oraz Władysław Witwicki - jeden z ojców-założycieli Polskiej Szkoły Psychologicznej. W czasie swej 35-letniej kariery akademickiej Twardowski wypromował dziesiątki doktorów, wśród których było ponad 20 późniejszych profesorów tytularnych. W dwudziestoleciu międzywojennym zajęli oni większość polskich katedr filozofii, logiki i psychologii, ale oddziałali także na inne dyscypliny - takie jak literaturoznawstwo, językoznawstwo, socjologia, muzykologia itp.

Twardowski zmarł w 1938 r., a za koniec Szkoły niektórzy przyjmują rok 1939. Istotnie, II wojna światowa spowodowała spustoszenie w szeregach jego uczniów, a jeszcze silniejszy cios stanowił dla niej okres stalinizmu. Kilka wybitnych postaci Szkoły - takich jak Kazimierz Ajdukiewicz, Tadeusz Czeżowski, Izydora Dąmbska, Maria Kokoszyńska-Lutmanowa, Janina Kotarbińska, Tadeusz Kotarbiński, Stefan Świeżawski, Władysław Tatarkiewicz - działało na szczęście w kraju jeszcze wiele lat po wojnie, wychowując kolejnych uczniów w duchu właściwego Szkole antyirracjonalizmu.

Historycy Szkoły podkreślaja, że jej spoiwem nie był żaden zespół idei, który wyznawaliby wspólnie jej przedstawiciele, lecz pewne postulaty metodologiczne oraz pewien zestaw wartości, które były w jej obrębie przekazywane kolejnym pokoleniom. Owe postulaty to przede wszystkim postulat precyzji wypowiedzi i postulat należytego uzasadnienia przekonań, a także postulat rzetelnej wymiany myśli. Wymagalniki takie pozornie wydają się czymś naturalnym dla całej roboty filozoficznej czy, szerzej, naukowej. W każdej pracy naukowej dbać bowiem należy o to, aby tezy wyrażone były z maksymalną jasnością i aby były należycie uzasadnione, a dyskusje naukowe winny służyć za wzór rzetelności. W praktyce niestety nie każda praca naukowa, a już zwłaszcza nie każda praca filozoficzna, postulaty te spełnia. Tymczasem w Szkole Lwowsko-Warszawskiej do ich realizacji przywiązywano wielką wagę i starano się do nich w możliwie największym zakresie stosować. Na gruncie filozofii, borykającej się przez całe tysiąclecia $z$ wieloma trudnościami metodologicznymi, szansę na realizację postulatów metodologicznych znaleziono w narzędziach szeroko rozumianej logiki.

W Szkole Lwowsko-Warszawskiej, a zwłaszcza w jej odnodze warszawskiej, uprawiano logikę formalną niezależnie od jej zastosowań filozoficznych. I to właśnie wyniki logiczne (obejmujące systemy wielowartościowe i metalogikę Łukasiewicza, gramatykę kategorialną Ajdukiewicza, 
semantykę Alfreda Tarskiego itd.) najszybciej znalazły uznanie za granica, stając się naszym „,towarem eksportowym”. Mniej znane w świecie są pozalogiczne osiągnięcia przedstawicieli Szkoły, do dziś odkrywane i cieszące się coraz większym zainteresowaniem. Wolno nawet powiedzieć, że zainteresowanie szkołą przeżywa ostatnio renesans.

Przejdę teraz do omówienia kolejnych dylematów cywilizacyjnych i do sposobów poradzenia sobie z nimi, które wyczytać można u koryfeuszy Szkoły Lwowsko-Warszawskiej.

\section{Dylematy polityczne}

Pierwszy dylemat kultury politycznej da się wyrazić w przeciwstawieniu: demokracja czy ochlokracja - rządy obywateli czy rządy tłumu?

Twardowski stawiał sprawę następująco: tylko naród odpowiednio przygotowany może unieść ciężar demokracji. A przygotowanie to osiąga się przede wszystkim przez wychowanie - w domu i w szkole. Twardowski poświęcił się głównie nauczaniu na poziomie uniwersyteckim, ale żywo angażował się także w nauczanie na niższych szczeblach: już w 1901 r. wydał znakomity podręcznik dla nauczycieli szkół powszechnych i przez wiele lat przewodniczył Towarzystwu Nauczycieli Szkół Wyższych (co w ówczesnej terminologii oznaczało - szkół średnich), które pod jego prezesurą stało się niezwykle wpływową instytucją publiczną.

Oto, jak wyrażał Twardowski swoje przekonanie o roli szkoły i wychowania w dążeniu do kształtowania dojrzałego społeczeństwa:

Są [...] rzeczy nieszkodliwe albo nawet pożyteczne dla narodów, zabezpieczonych własnym bytem politycznym, które jednak w naszym położeniu politycznym muszą osłabiać niezbędną dla naszego istnienia postawę obronną. I tak przeciwieństwa poglądów i interesów nie dadzą się w zupełności usunąć nawet w obrębie jednego narodu i społeczeństwa, lecz w naszym wyjątkowym położeniu należy zakreślić im pewne granice, nałożyć pewne więzy. A co do tego złagodzenia walk i sporów trzeba gotowości z obu stron. Bo gdyby tylko jedna była do tego skłonna, a druga nie, [ta druga] mogłaby te skłonności wyzyskać i odnieść łatwe zwycięstwo [nad pierwszą]. By tak się stało, trzeba nam wypielęgnować dojrzałość narodową i delikatność sumienia zbiorowego Narodu. Może ono być wytworem konsekwentnej i celowej pracy wielu czynników, a jednym z najważniejszych z nich jest szkoła (Twardowski [1911b] 2014, s. 371).

Słowa te są w pełni aktualne także dzisiaj. „Wyjątkowe położenie” naszego narodu oznaczało w $1911 \mathrm{r}$. niewolę i rozdarcie na trzy zabory. Ale i dziś jest ono trudne, chociaż nie ma już niewoli i rozdarcia rozbiorowego. Różnice w poglądach politycznych, skądinąd naturalne w każdym społeczeństwie, wyolbrzymiane są do monstrualnych rozmiarów: 
gotowości do porozumienia na ogół brak. Być może dlatego, że potrzeba więcej niż 30 lat suwerenności i integralności terytorialnej na odbudowanie więzi narodowej w społeczeństwie spustoszonym wielką wojną i 50 latami komunizmu.

Kolejny dylemat kultury politycznej wyraża się w przeciwstawieniu: patriotyzm czy kosmopolityzm?

Twardowski, wychowany w domu, którego atmosferę określał jako „umiarkowanie religijna, ale żarliwie patriotyczną" ${ }^{2}$, nie miał najmniejszych wątpliwości, że z tego przeciwstawienia należy wybrać patriotyzm. Oto, jak uzasadniał potrzebę zajmowania postawy patriotycznej i jak tę postawę rozumiał:

Rdzeniem każdego patriotyzmu jest poczucie solidarności ogólnonarodowej: to poczucie, które nie dozwala nam być obojętnymi na los innych Polaków, gdziekolwiek byliby przebywali, w stronach bliskich czy dalekich [...]. Gdzie poczucie solidarności narodowej objawia się tylko w uczuciu, a nie prowadzi do czynu i do działania, tam nie ma jeszcze prawdziwego patriotyzmu - tam jest tylko patriotnictwo. Patriotnik chętnie daje upust swym uczuciom narodowym, pięknie i podniośle o Polsce rozprawia, z przejęciem śpiewa pieśni narodowe, bierze pilnie udział $\mathrm{w}$ obchodach narodowych - ale na tym się też wszystko u niego kończy (Twardowski [1919] 2013, s. 447-448).

Ów „rdzeń patriotyzmu”, poczucie narodowej solidarności, przejawiać się ma przede wszystkim w solidnej pracy dla kraju - w każdej dziedzinie i w każdym zawodzie. Drażnił Twardowskiego, który urodził się i wychował w Wiedniu, rozpowszechniony tam stereotyp Polaka, na który składały się m.in. lenistwo i niechlujstwo. Stereotyp ten niestety w dużym stopniu się potwierdził, gdy Twardowski przeniósł się do Lwowa. Robił więc wszystko, żeby na polu swojej działalności, a więc w Uniwersytecie i w ramach szkolnictwa filozoficznego, elementy tego stereotypu zwalczać. Pisał:

Powinniśmy ze wszystkich sił dążyć ku temu, aby Państwo Polskie godnie mogło stanąć obok najświetniejszych państw świata i w niczym im nie ustępowało. I każdy może w tym duchu działać i pracować. Wódz, dbając o to, by wojsko polskie najlepiej było zorganizowane i wyćwiczone; żołnierz polski, dowodząc, że jest najwaleczniejszym i zarazem najkarniejszym żołnierzem na świecie; urzędnik, starając się o to, by jego biuro słynęło z obywatelskiego i szybkiego załatwiania poruczonych mu spraw; rolnik, dążąc do tego, by uprawiana przez niego ziemia jak najobfitsze wydawała plony; rzemieślnik, zmierzając do tego, by wychodzące $z$ warsztatu jego wyroby były jak najlepsze i jak najtańsze; kupiec, pamiętający o tym, by nikt nigdy nie mógł mu zarzucić choćby najdrobniejszej nierzetelności. Można by przytoczyć po kolei wszystkie zawody, bo

2 Twardowski [1926] 2014, s. 35. 
w każdym zawodzie i na najbardziej niepozornych stanowiskach można i należy kierować się w działaniu ambicją patriotyczna, wyrosłą na gruncie gorącej miłości Ojczyzny (Twardowski [1919] 2013, s. 449).

Twardowski uczył swych uczniów wytrwałej i rzetelnej roboty na polu filozofii, co przyniosło wspomniane już wyżej znakomite rezultaty. Środkiem, jaki stosował, były żelazna dyscyplina i niewzruszone zasady, które niejednego raziły, ale których przestrzeganie w końcu procentowało w życiu każdego, kto ich przestrzegał. Ostatecznie zostawali przy Twardowskim ludzie nie tylko o największych zdolnościach intelektualnych, ale i o najtwardszych charakterach - i to oni potem kontynuowali jego dzieło.

Twardowski był przekonany, że istotne dla kultury polskiej jest kultywowanie jej swoistych wartości i zachowywanie odpowiedniego dystansu wobec obcych wpływów, zwłaszcza jednostronnych. Chodziło o to, aby kultura polska nie rozpłynęła się w innych, silniejszych, często dążących do dominacji nad nią. Uważał, że jak wychowanie jednostki nie może zacierać jej indywidualności, tak wychowanie narodu nie może jej zatracać:

Biorąc $[\ldots]$ udział w pracy kulturalnej całej ludzkości, nie przestajemy być narodem odrębnym, o odrębnej przeszłości dziejowej, o odrębnych cechach plemiennych. Mało cenimy człowieka, który nie przedstawia tzw. wyrobionej indywidualności, który nie czuje się sobą, lecz, jak trzcina na wietrze, ulega wpływom otoczenia, krocząc przez życie jako przykry okaz chwiejności i niesamodzielności. I dlatego żądamy słusznie, by wychowanie nie zacierało osobniczych cech jednostki ludzkiej, by nie niwelowało indywidualności, by nie czyniło z ludzi marionetek i niczym się od siebie nie różniących pionków. To samo trzeba stosować do całych narodów. Naród, który nie ceni swej odrębności, który przyjmuje wpływy obce w tym stopniu, że zacierają jego własną indywidualność, który nie czuje się i nie chce zawsze pozostać sobą, naród taki ani poważaniem, ani wpływem w społeczności narodów cieszyć się nie może (Twardowski [1905] 1912, s. 144).

Także w XXI w. naród polski znajduje się pod presją nieraz bardzo silnych, choć innych niż w czasach Twardowskiego zbiorowości zewnętrznych. Potrzeba zachowania - mimo tej presji - indywidualności narodowej bierze się z przekonania o wartości narodu jako takiego: wartości, którą z pewnością uznawał Twardowski, ale która bywa dziś często podważana. W jakie relacje $\mathrm{z}$ innymi kulturami winna wchodzić kultura polska? Czy trzeba nam kooperacji, czy powinniśmy skapitulować? Czy powinniśmy poszukiwać oryginalności, czy dać się skazać na peryferyjność? Czy powinien nam przyświecać ideał ekspansji, czy recepcji?

Twardowski w ten sposób rozwiązywał te dylematy w odniesieniu do polskiej filozofii: 
Nie powinniśmy ulegać jednostronnemu wpływowi tego lub owego kierunku, ani nawet tego lub owego narodu. Naszymi przewodnikami nie powinni być ani Anglicy, ani Francuzi, ani Niemcy wyłącznie, lecz wszyscy razem. Jesteśmy w tym szczęśliwym położeniu, że trzy przodujące w filozofii narody są nam $\mathrm{w}$ równej mierze obce, a przeto $\mathrm{w}$ równej mierze bliskie. I nie wolno nam dogmatycznie wierzyć, że ten lub ów z wymienionych narodów jest [...] narodem filozoficznym; musimy w pracy naszej opierać się na tym, co zdziałał każdy z nich. Nie wolno nam się dać opanować wpływom obcym, lecz musimy sami nad nimi zapanować i posiłkując się tym, co po sumiennym zbadania wyda się doniosłym, samodzielnie brać udział w pracy wspólnej ([1904] 2014, s. 334).

„Jednolity pochód filozofii narodowej" możliwy jest tylko wtedy, jeżeli pochód ten ma swoisty kierunek i jeżeli wpływy obce, z zewnątrz pochodzące, nie zdołają go tego kierunku swoistego pozbawić. Niekiedy jednak [...] obce [...] wpływy, zamiast pobudzać i ożywiać własną myśl filozoficzną narodu, pochłaniają ją i zupełnie od siebie uzależniają. Miejsce dobroczynnego odDzıAŁYwANiA myśli obcej na własną zajmuje wtedy inwazja myśli obcej, nie dopuszczając rozwoju filozofii rodzimej ([1911a] 1927, s. 391).

Taki stan rzeczy, którego przykładów dostarcza każda niemal karta dziejów filozofii w Polce, wytwarza się nieuchronnie, ilekroć myśl obca, z którą się spotka własna, przewyższa ją bogactwem, głębokością, rozmachem. To, co słabsze, ulega silniejszemu także $\mathrm{w}$ dziedzinie myśli. Więc tylko wtedy rodzime dążności filozoficzne moga, nie narażając się na niebezpieczeństwo zaniku, owszem, z wielką dla siebie korzyścia, ulegać wpływom ościennym, jeżeli same posiadają dostateczny stopień rozwoju i mocy ([1911a] 1927, s. 392).

W dziedzinie filozofii udało się Twardowskiemu i jego uczniom w ciągu jednego pokolenia stworzyć szkołę filozoficzna, która wydała wyniki o trwałej, uniwersalnej wartości. Udało się to m.in. dlatego, że Twardowski nie kopiował żadnych rozwiązań obcych, lecz mozolnie wypracował własne. Stworzył coś po swojemu, ale zrobił to dobrze. Czy powtórzenie takiego sukcesu jest możliwe? Na pewno nie, gdy z góry zakłada się, że zewnętrzne trendy są „lepsze” od naszych, i daje się im pieczęć „światowości".

Inny dylemat kultury politycznej brzmi następująco: czy kierować ma nami szacunek dla tradycji (tradycjonalizm), czy jej kontestacja? Twardowski pisał o tym krótko i dobitnie:

Żadnej generacji nie wolno być tak zarozumiała, by sądziła, że to, co stworzyła, jest najlepsze. Każda generacja, która chce spojrzeć w przyszłość, musi się oprzeć na gruncie przeszłości ([1913] 2014, s. 374).

W Szkole Twardowskiego ów szacunek do tradycji filozoficznej przejawiał się w tym, że żadnych dawnych problemów filozoficznych nie odrzucano z góry, a spory i stanowiska przeszłości poddawano gruntownej 
analizie i rekonstrukcji. Dawało to Szkole w dziedzinie filozofii przewagę nad innymi nurtami filozofii analitycznej, propagującej bardziej gwałtowne zerwanie $\mathrm{z}$ tradycją.

Jak tę postawę ekstrapolować na kulturę w ogóle? Oczywiście: nie wszystko, czego dostarcza nam tradycja, warte jest zachowania. Zamiast jednak apriorycznie odrzucać tradycję jako całość, należałoby poddać ją dostatecznie głębokiej analizie - i dopiero po jej przeprowadzeniu ocenić, które elementy warte są zachowania, a które wymagają przebudowy. $\mathrm{W}$ ostatnich latach wiele się $\mathrm{w}$ tym kierunku robi, ale nadal duże obszary naszej tradycji są białymi plamami, kwitowanymi przez historyków powierzchownymi etykietami wartościującymi.

\section{Dylematy kultury logicznej}

Przejdźmy teraz do dylematów kultury logicznej.

Pierwszy z nich wyrazić można następująco: naturalna ekspresja (komunikatywność, prostota, precyzja wypowiedzi) czy peryfrastyczna cenzura (układność polityczna, mętność)?

Kultura logiczna - to to, co wyróżnia prace wszystkich przedstawicieli Szkoły Lwowsko-Warszawskiej, niezależnie od tego, jaką gałąź nauki reprezentowali. Objawiała się ona w traktowaniu serio wspomnianych wyżej postulatów metodologicznych, na które w Szkole kładziono nacisk szczególny (niekiedy nawet może przesadny).

Dla Twardowskiego przejawem kultury logicznej były jednak nie tylko ścisłość wypowiedzi i wywodu naukowego, ale też racjonalna dyscyplina we wszelkim myśleniu i działaniu. Oto, jak rozumiał rolę filozofa w tym zakresie:

Znikąd [...] nie spływa na człowieka trwalsze i czystsze zadowolenie, jak $\mathrm{z}$ bezinteresownego szukania prawdy naukowej. A najwyższe z tego źródła zadowolenie czerpie chyba ten, kto, prawdy tej szukając, zarazem zastanawia się zarówno nad nią sama, jak też nad najdoskonalszymi sposobami jej zdobywania. Jest to zadaniem filozofii i dlatego filozofia zajmuje wśród nauk miejsce centralne. Czyniąc przedmiotem swych badań samą prawdę, rozświetlając drogi ku niej wiodące, tworząc teorię naukowego poznania, filozofia staje się sojuszniczką i przewodniczką wszystkich, którzy na jakimkolwiek polu dociekań ludzkich dążą ku prawdzie. Budzi w nas krytycyzm, który chroni nas od ślepego ulegania autorytetom, od wygodnego poprzestawania na miłych nam nawyczkach intelektualnych, a także od zbytniego dufania w nasz ludzki, tak bardzo ograniczony rozum; każe nam domagać się jasności i ścisłości wszędzie tam, gdzie chodzi o stosowanie naukowej argumentacji, a zwalczać wszelakiego rodzaju męty myślowe, które pragną swoją odurzającą mglistością zastąpić uchwytność szczegółów i przejrzystość całości; uczy nas prześwietlać 
liczne pojęcia, którymi posługują się, nie wnikając w nie głębiej, nauki szczegółowe, i pozwala nam uświadamiać sobie nie mniej liczne założenia, którymi kierujemy się w rozważaniach i działaniach życia potocznego, w codziennej jego praktyce. Albowiem także w tej dziedzinie rzeczą znamienną dla filozofa jest to, że nie poprzestaje on na wykonywaniu obranych mniej lub więcej dobrowolnie czynności, lecz że się nad tym, co czyni, zastanawia, że postępowanie swoje, jego pobudki, metody i cele czyni przedmiotem własnej refleksji (Twardowski $1933, \S 16$, s. 15-16).

W przekonaniu Twardowskiego logika, rozumiana jako organon nie tylko filozofii, ale też wszelkiej nauki i w ogóle myślenia, może nas uchronić przed błędami w procesach myślowych, a w konsekwencji także w działaniu. Jest także środkiem uzyskiwania niezależności myślenia. Chociaż nie potrafimy uniezależnić się od wszelkich wpływów, to jednak możemy wyzwolić się od nich częściowo i posiąść świadomość pozostałych ograniczeń. Twardowski pisał:

Kapłanami piękna są artyści, kapłanami myśli niezależnej są ludzie nauki. Nigdzie poza ich gronem myśl niezależna nie jest podniesiona do godności zasady życiowej; oni jedni z całą świadomością pracują nad tym, by uczynić myśl tak niezależna, jak to w ogóle człowiekowi jest możliwe ([1906] 2013, s. 73).

Kolejny dylemat kultury logicznej brzmi: dogmatyzm czy antydogmatyzm? Twardowski opowiadał się, rzecz jasna, za antydogmatyzmem. Pisał:

Dogmatyzm jest największym wrogiem wszelkiej pracy naukowej. [...] [Nauka i filozofia zmierza] ku wyświetleniu prawdy. Drogą ku temu [jest] - naukowy krytycyzm; on powinien nas uchronić od wszelkich uprzedzeń i formułek, z góry narzuconych lub dobrowolnie przyjętych (Twardowski [1904] 2014, s. 333).

Słowa te wypowiedział Twardowski w przemówieniu inaugurującym pierwsze zebranie Polskiego Towarzystwa Filozoficznego we Lwowie, które powstało z jego inicjatywy. Podczas tego przemówienia padły jego słynne słowa: że jedynym dogmatem PTF - jako towarzystwa naukowego - ma być... brak dogmatów.

„Świątynią" antydogmatyzmu miał być - według Twardowskiego - uniwersytet. Dziś również trzeba o tym pamiętać.

Ostatni z najważniejszych dylematów kultury logicznej wyraża się $\mathrm{w}$ alternatywie: absolutyzm czy relatywizm aletyczny?

Twardowski opowiedział się stanowczo za absolutyzmem $\mathrm{w}$ teorii prawdy - i pociągnął za sobą większość ze swoich uczniów. Nie była to jednak bezkrytyczna akceptacja wyboru dokonanego przez mistrza. 
Dyskusje, które w Szkole prowadzono na temat prawdy, zaowocowały ważnymi wynikami w dziedzinie filozofii i logiki.

Oto, jak Twardowski swój pogląd wyrażał:

Sąd każdy albo jest prawdziwy, a wtedy jest zawsze i wszędzie prawdziwy, albo też nie jest prawdziwy, a wtedy też nie jest nigdy i nigdzie prawdziwy. Nauka o istnieniu prawd względnych utrzymać się może jedynie dzięki nierozróżnianiu sądów od powiedzeń i traci wszelką podstawę tam, gdzie różnica między sądami a powiedzeniami jest ściśle i konsekwentnie przestrzegana ([1901] 2014, s. 336).

I tutaj znowu - podobnie jak w wypadku antydogmatyzmu - ostoją absolutyzmu aletycznego powinien być przede wszystkim uniwersytet. Dlatego właśnie Twardowski opowiadał się stanowczo za niezależnością uniwersytetu od wszelkich instytucji, które na proces zdobywania prawd naukowych chciałyby mieć wpływ, a tym bardziej taką czy inną "prawdę" uniwersytetowi narzucić.

Uniwersytet ma [...] obowiązek unikania [...] wszystkiego, co by mogło tę niezawisłość nadwyrężać lub stwarzać chociażby pozory ulegania jakimkolwiek wpływom lub dążnościom, nie mającym nic wspólnego $\mathrm{z}$ badaniem naukowym i jego celem. Musi odgradzać się od wszystkiego, co nie służy zdobywaniu prawdy naukowej, musi przestrzegać należytego dystansu między sobą a nurtem, którym niknie około jego murów życie dnia potocznego, zgiełk ścierających się prądów społecznych, ekonomicznych, politycznych i wszelakich innych; wśród walk i zmagań się tych najrozmaitszych prądów Uniwersytet winien trwać niewzruszenie jak latarnia morska, która wskazuje swym światłem okrętom drogę przez wzburzone fale, lecz nigdy światła swego nie nurza w samych falach. Gdyby to uczyniła, światło by zgasło, a okręty pozostałyby bez gwiazdy przewodniej (Twardowski 1933, § 7, s. 6-7).

Nie trzeba chyba nikogo przekonywać, że próby narzucania światu akademickiemu różnych pseudoprawd, wygodnych dla tych czy innych grup nacisku, bynajmniej nie ustały. Być może jedną z dróg, aby te próby zneutralizować, byłoby samoograniczenie się naukowców w zakresie ekspresji swoich preferencji politycznych, by nie „nurzać” nauki w bieżącej grze interesów.

\section{Dylematy aksjologiczne}

Główny dylemat kultury etycznej wyraża się w alternatywie: absolutyzm czy relatywizm aksjologiczny?

Twardowski był absolutystą także w dziedzinie aksjologii: etyki i estetyki. W tym duchu krytykował w szczególności etykę ewolucjonistyczna, 
głosząca, iż normy moralne ewoluują wraz z ewolucją człowieka. Jest faktem, że przedstawiciele rożnych kultur wyznają rożne zasady etyczne i że nawet $\mathrm{w}$ ramach jednego kręgu kulturowego w różnych epokach uznawane bywają odmienne systemy etyczne. Nie jest to jednak świadectwem ewolucji norm etycznych, lecz ewolucji - „dojrzewania” - ludzkości. Prawdy etyczne są prawdami niezmiennymi w czasie, ale ludzie bywają z różnych względów na nie „ślepi” i na ogół odkrywają je oni stopniowo. Podobnie jest z wszelkimi prawdami naukowymi, w tym prawami logiki; są one stopniowo odkrywane.

Twardowski pisał:

Jeżeli jest prawda, że Mickiewicz urodził się 1798 roku, jeżeli jest prawda, że bliźniego trzeba kochać, jeżeli jest prawda, że symfonie Beethovena są piękne, wtedy prawdy te są zawsze i wszędzie prawdami. Nie prawdy przechodzą kolejno przez kolejne stopnie rozwoju [...], lecz ludzkość się przeobraża, rozwija pod względem rozumu, sumienia i smaku estetycznego, i dlatego wyzbywa się coraz więcej błędów, a dochodzi do odkrycia coraz nowych, nieznanych jej dotąd prawd wiekuistych ([1895] 1927, s. 356).

W ocenie Twardowskiego nie jest też prawda, jakoby $w$ etyce nie było pewników, tj. zdań niepowątpiewalnych, oczywistych. Rozbieżności w ocenach etycznych biorą się stąd, iż rozpoznanie prawd etycznych, odnoszących się do dobra i zła, wymaga szczególnych umiejętności - dojrzałości sumienia i wyrobienia uczuciowego. Dojrzałość taką osiąga się o wiele trudniej niż dojrzałość intelektualną. Nic więc dziwnego, że łatwiej odkryć pewniki logiczne niż pewniki etyczne.

Jedynie geniusz etyczny - a za takiego geniusza uważał Twardowski np. Jezusa z Nazaretu - widzi prawdy etyczne od razu: jasno i wyraźnie.

Sformułujmy na koniec najistotniejszy dylemat w zakresie kultury artystycznej: artyzm (apollinizm, elitaryzm) czy tandeta (dionizyjskość, jarmarczność)?

Twardowski i jego uczniowie opowiadali się za pierwszym członem tego dylematu ${ }^{3}$. O tym, jaką wagę przywiązywali do artyzmu, świadczy to, że postulowali nie tylko, aby sztuka była „,apollińska”, lecz także by artyzm cechował również inne dziedziny kultury - np. dzieła filozoficzne.

Twardowski pisał:

Jakże wielu autorów publikuje w zakresie filozofii artykuły, rozprawy, a nawet obszerne tomy, w których wprost roi się od ekwiwokacji, niezrozumiałości, przeskoków myślowych, niekonsekwencji, niejasnych wyrażeń i paralogizmów, i którzy wraz ze swoimi wydawcami niczego przy tym nie tracą wywołując

${ }^{3}$ To nie przypadek, że zaliczający się do Szkoły Lwowsko-Warszawskiej Tatarkiewicz opublikował traktat $O$ doskonałości. 
w szerokich kręgach czytelniczych odgłos, a często i podziw! Autorom takim mógłbym zazdrościć łatwości ich literackiej produkcji, gdybym nie lekceważył produktów ich pióra i nie oburzał się na ich postępowanie wysoce szkodliwe dla rozwoju ściśle logicznego myślenia filozoficznego ([1926] 2014, s. 48).

Wprost postulat dążenia do piękna w zakresie twórczości naukowej formułował jeden z najstarszych uczniów Twardowskiego - Łukasiewicz:

Żadna myśl twórcza, nawet najgenialniejsza, nie ma wartości naukowej, dopóki nie zostaje ujęta w słowa i nie stanie się w ten sposób dostępna ludzkości. Niech więc każdy przyszły twórca naukowy uczy się swe myśli wyrażać w słowach; niech dba o swój język i stara się pisać nie tylko prosto i jasno, z nieubłaganą ścisłością logiczną ale zajmująco i pięknie. Tylko piękne dzieła przetrwają wieki, wpływ swój wywierając na coraz dalsze pokolenia (1912, s. 32-33).

Kiedy się dzisiaj zwiedza galerie sztuki nowoczesnej, ogląda spektakle teatralne, a tym bardziej kiedy obcuje się z "produkcją artystyczną" dostępną w mediach masowych - widać jak na dłoni, że w sztukę coraz częściej wkrada się nie tylko brzydota, lecz także po prostu tandeta. Jeśli więc współczesny artysta nie chce zadowolić się chwilowym, „,karnawałowym" sukcesem, warto, aby pamiętał o zacytowanej opinii Łukasiewicza, że "tylko piękne dzieła przetrwają wieki".

\section{Uwagi końcowe}

Takie właśnie odpowiedzi na dylematy cywilizacyjne wyłaniają się z programu sformułowanego przez Twardowskiego. Czy jest to program aktualny? Tak - a nawet więcej: dziś dylematy, przed którymi staje nasza kultura, są może wyraźniejsze niż przez stu laty. Czy jest to program dla wszystkich? Nie; nie jest dla tych, którzy jawnie odrzucają elementarne postulaty antyirracjonalizmu. Nie zaakceptuje go współczesny „,barbarzyńca".

Program Twardowskiego to jednak program dla wielu. Jest to program dla „jasnościowców” - a więc dla tych wszystkich, którzy zgadzają się ze sformułowanym $\mathrm{w}$ prostych słowach ponad dwieście lat temu postulatem wspomnianego na początku tego tekstu Jarońskiego: dążyć do tego „by wyrazy codziennie używane, np. "piękność», "porządek», «doskonałość», «uczciwość», «honor» itp. tak jasne były dla każdego, jak są np. wyrazy «dwa», «dziewięć», «rzeczownik», «zaimek», «trójkąt»itp." (Jaroński 1810, s. 34). I dla tych, którzy podpisują się pod jego hasłem:

Niech człowiek to, co umie, zastosowuje do większego siebie doskonalenia, to jest do zrządzenia sobie większej moralności i szczęścia (Jaroński [1810] 1970, s. 15). 
Jest to program niedoktrynerów - a więc dla tych wszystkich, którzy doceniają wagę rozumnej tolerancji, jaka charakteryzowała w najwyższym stopniu Twardowskiego. Nie deprecjonował on poglądów swych uczniów, nawet gdy skrajnie odbiegały od jego własnych - oczekiwał jedynie jasnego wysłowienia i podania explicite racji, które za tymi poglądami miały przemawiać. Był wobec swych uczniów maksymalnie obiektywny: w ocenie ich osiągnięć brał pod uwagę wyłącznie względy merytoryczne. To dlatego wśród przedstawicieli Szkoły Lwowsko-Warszawskiej znalazły się osoby o różnych światopoglądach i - dodajmy - różnych narodowościach.

Również w obrębie kultury jako takiej program antyirracjonalizmu dopuszcza różne stanowiska, byleby ci, którzy je głoszą, akceptowali pewne aksjologiczne minimum. Antyirracjonalista wie, że w sprawach politycznych i moralnych nie ma stanowisk uzasadnionych w stopniu takim, w jakim uzasadnione mogą i powinny być np. twierdzenia naukowe. Zarazem jednak to właśnie $w$ tych sprawach jednostki i społeczeństwa zmuszone są podejmować decyzje, od których zależy nieraz w decydującym stopniu ich dalszy los. Antyirracjonalista wie jednak także, że szeroko rozumiana logika dostarcza narzędzi do analizy treści różnych poglądów i stopnia ich uzasadnień, a pośrednio także do wypracowania kompromisów i podejmowania właściwych decyzji.

Dodajmy na koniec, że tam, gdzie nie można przekonań czy wyborów uzasadnić w stopniu wystarczającym, tam można i trzeba posłużyć się odpowiednimi przykładami. Twardowski i jego uczniowie dostarczali własnym życiem przykładów postaw antyirracjonalnych w działaniu.

\section{Bibliografia}

Jaroński F. [1810] (1970), Jakiej filozofii Polacy potrzebują?, [w:] W. Tatarkiewicz (1970), Jakiej filozofii Polacy potrzebuja?, PWN, Warszawa, s. 3-42.

Łukasiewicz J. [1912] (1998), O twórczości w nauce, [w:] idem, Logika i metafizyka, Wydawnictwo WFiS UW, Warszawa, s. 9-33.

Łukasiewicz J. (1998), Logika i metafizyka, Wydawnictwo WFiS UW, Warszawa.

Tatarkiewicz W. (1970), Jakiej filozofii Polacy potrzebuja?, PWN, Warszawa.

Twardowski K. [1895] (1927), Etyka wobec teorii ewolucji, [w:] idem, Rozprawy i artykuły filozoficzne, Książnica-Atlas, Lwów, s. 343-356.

Twardowski K. [1901] (2014), Przemówienie na inauguracji III roku Powszechnych Wykładów Uniwersyteckich, [w:] idem, Myśl, mowa i czyn, cz. 2, Wydawnictwo Naukowe Semper, Warszawa, s. 321-326.

Twardowski K. [1904] (2014), Przemówienie na otwarciu Polskiego Towarzystwa Filozoficznego, [w:] idem, Myśl, mowa i czyn, cz. 2, Wydawnictwo Naukowe Semper, Warszawa, s. 329-334.

Twardowski K. [1905] (1912), Unarodowienie szkoty, [w:] idem, Mowy i rozprawy z okresu [...] jego działalności w Towarzystwie Nauczycieli Szkót Wyższych, s. 142-152. 
Twardowski K. [1906] (2013), Niezależność myśli, [w:] idem, Myśl, mowa i czyn, cz. 1, Copernicus Center Press, Kraków, s. 63-74.

Twardowski K. [1911a] (1927), Jeszcze stówko o polskiej filozofii narodowej, [w:] K. Twardowski, Rozprawy i artykuty filozoficzne, Książnica-Atlas, Lwów, s. 391-393.

Twardowski K. [1911b] (2014), Zagajenie III Zjazdu Członków Towarzystwa Nauczycieli Szkót Wyższych, [w:] idem, Myśl, mowa i czyn, cz. 2, Wydawnictwo Naukowe Semper, Warszawa, s. 368-340.

Twardowski K. (1912), Mowy i rozprawy z okresu [...] jego działalności w Towarzystwie Nauczycieli Szkół Wyższych, TNSW, Lwów.

Twardowski K. [1913] (2014), Przemówienie z okazji otwarcia siedziby Polskiego Muzeum Szkolnego we Lwowie, [w:] idem, Myśl, mowa i czyn, cz. 2, Wydawnictwo Naukowe Semper, Warszawa, s. 373-375.

Twardowski K. [1919] (2013), O patriotyzmie, [w:] idem, Myśl, mowa i czyn, cz. 1, Copernicus Center Press, Kraków, s. 436-455.

Twardowski K. [1926] (2014), Autobiografia, [w:] idem, Myśl, mowa i czyn, cz. 2, Wydawnictwo Naukowe Semper, Warszawa, s. 35-49.

Twardowski K. (1927), Rozprawy i artykuły filozoficzne, Książnica-Atlas, Lwów.

Twardowski K. (1933), O dostojeństwie uniwersytetu, Uniwersytet Poznański, Poznań.

Twardowski K. (2013), Myśl, mowa i czyn, cz. 1, Copernicus Center Press, Kraków.

Twardowski K. (2014), Myśl, mowa i czyn, cz. 2, Wydawnictwo Naukowe Semper, Warszawa.

Streszczenie: Jakiej kultury Polacy potrzebuja? Antyirracjonalizm wobec dylematów cywilizacyjnych

"Antyirracjonalizm" to hasło, które krótko charakteryzuje Szkołę Lwowsko-Warszawską - formację zainicjowaną na przełomie XIX i XX w. przez K. Twardowskiego. W filozofii, która była głównym przedmiotem zainteresowań Szkoły, realizowano je, przede wszystkim przestrzegając dwóch postulatów: jasności wypowiedzi i należytego uzasadnienia twierdzeń. Antyirracjonalizm to jednak postawa, która daleko wykracza poza działalność stricte naukową i sięga w różne sfery działalności ludzkiej. W artykule przedstawiam pewne dylematy współczesnej cywilizacji, które określam jako "polityczne”, ,logiczne” i "aksjologiczne”. Opierając się na wypowiedziach Twardowskiego oraz pewnych faktach $\mathrm{z}$ dziejów Szkoły Lwowsko-Warszawskiej, pokazuję, jakie odpowiedzi na te dylematy proponuje program antyirracjonalizmu.

Słowa kluczowe: antyirracjonalizm, cywilizacja, Szkoła Lwowsko-Warszawska, Kazimierz Twardowski

Summary: What Kind of Culture do Poles Need? Antiirrationalism towards the Dilemmas of Civilization

"Antiirationalism" is a term which shortly characterizes the Lvov-Warsaw School, a group founded by Kazimierz Twardowski at the turn of the $19^{\text {th }}$ century. In philosophy, which was the main object of interest of the School, antiirrationalism was realized by applying two postulates: 
Jakiej kultury Polacy potrzebują? Antyirracjonalizm wobec dylematów...

the postulate of clearness of language and the postulate of appropriate justification of statements. However, antiirrationalism as a certain attitude goes far beyond the philosophy sensu stricto and reaches various spheres of human activities. In the article, I present some dilemmas of the contemporary civilization which I call "political", "logical" and "axiological" respectively. Based on various Twardowski's statements and some facts from the history of the Lvov-Warsaw School, I show what answers to these dilemmas are dictated by the program of antiirrationalism.

Keywords: antiirationalism, civilization, Lvov-Warsaw School, Kazimierz Twardowski 